Témoigner Témoigner. Entre histoire et mémoire

Getuigen Revue pluridisciplinaire de la Fondation Auschwitz

$125 \mid 2017$

Histoire et mémoire de la persécution des

homosexuel-le's par les nazis

\title{
De vervolging van homoseksuelen tijdens het naziregime
}

La persécution des homosexuels sous le régime nazi

\section{Florence Tamagne}

Traducteur : Gorik de Henau

\section{(2) OpenEdition}

1 Journals

\section{Édition électronique}

URL : https://journals.openedition.org/temoigner/6387

DOI : 10.4000/temoigner.6387

ISSN : 2506-6390

Cet article est une traduction de :

La persécution des homosexuels sous le régime nazi - URL : https://journals.openedition.org/ temoigner/6342 [fr]

Éditeur :

Éditions du Centre d'études et de documentation Mémoire d'Auschwitz, Éditions Kimé

Édition imprimée

Date de publication : 1 octobre 2017

Pagination : $72-81$

ISBN : 978-2-930953-01-4

ISSN : 2031-4183

Référence électronique

Florence Tamagne, «De vervolging van homoseksuelen tijdens het naziregime», Témoigner. Entre

histoire et mémoire [Online], 125 | 2017, Online op 24 décembre 2021, geraadpleegd op 03 février 2022. URL: http://journals.openedition.org/temoigner/6387 ; DOI: https://doi.org/10.4000/temoigner.6387 


\section{De vervolging van \\ homoseksuelen \\ tijdens het naziregime}

$\rightarrow$ Florence Tamagne Ris-institut de recherches Vistoriques du Septentrion

Gorikde Henau

\section{DE WORTELS VAN HET HOMOFOBE NAZIVERTOO}

erwijl duizenden werken zijn geschreven over deportatie onder het naziregime blijft het lot van de 'roze driehoeken' bij het grote publiek tot op vandaag grotendeels onbekend. Behalve een paar baanbrekende werken (Grau 1995; Jellonnek 1990; Lautmann 1977; Plant 1986; Schilling 1983 Schoppmann 1991) wordt hierover pas sinds een jaar of twintig hoogstaand historisch onderzoek gepubliceerd. Omdat de kwestie van de homoseksuele

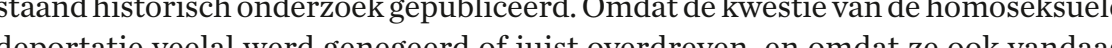
deportatie veelal werd genegeerd of juist overdreven, en ondat ze ook vandaag nog ter discussie staat, moeten we haar weer in een historische context plaatsen, namelijk die van het nazitotalitarisme en de onderdrukking van homoseksualiteit in Europa sinds de late negentiende eeuw. Homoseksuelen konden tijdens het Derde Rijk maar worden vervolgd omdat homofobe vooroordelen diep verankerd waren in de Europese en dus ook Duitse geesten, en omdat er al een repressief apparaat bestond voordat het naziregime zijn eigen bestraffing instelde.

Sinds 1871 voorzag paragraaf 175 van het Duitse wetboek van strafrecht, met bepalingen afkomstig uit de Pruisische rechtspraak, in een daadwerkelijke gevangenisstraf en het verlies van burgerrechten voor homoseksuele handelingen tussen mannen. De duur van de straf hing af van diverse factoren de ard van dentussen handeling (we partnerleeftijd, en recidive. Tijdens de Weimarrepubliek vonden gemiddeld zevenhonderd arrestaties per jaar plaats. Ongeveer tachtig procent van de gearresteerden werd veroordeeld, de meesten tot een straf van minder dan drie maanden opsluiting. Maar een dergelijke veroordeling stond gelijk met schandaal en schande, en door dreigementen van afpersing werden veel homoseksuelen tot zelfmoord gedreven Ondanks een poging hiertoe in 1909 werden relaties tussen vrouwen niet strafbaar gesteld, maar lesbische geaardheid werd in de anonimiteit gedrongen en lesbiennes gestigmatiseerd.

Toch kon zich eind negentiende eeuw in Duitsland zonder veel tegenkanting een bloeiende homoseksuele subcultuur ontwikkelen, hoofdzakelijk in grote kosmopolitische steden als Berlijn en Hamburg (Tamagne 2000). Tijdens de Weimarrepubliek stond Berlijn bekend om zijn gemaskerde bals en zijn veelsoortige ontmoetingsplek- ken voor homoseksuelen en lesbiennes. Nog in Duitsland ontstonden, opnieuw in de late negentiende eeuw, de eerste homoseksuele actiebewegingen. De bekendste was het WhK (Wissenchaftlich-humanitäres Komittee), opgericht door de homoseksuele seksuoloog en activist Magnus Hirschfeld. In 1897 was hij een petitie begonnen voor de afschaffing van paragraaf 175 , die al snel werd ondertekend door eminente figuren uit binnen- en buitenland. Ondanks herhaalde pogingen tijdens de jaren twintig en de steun van de democratische partij en de linkse partijen SPD en KPD de liep het project op niets uit, en door de algemene Duitse crisis tijdens de jaren dertig verschoof de strijd voor homorechten naar de achtergrond.

We moeten ook wijzen op de wijdverbreide vooroordelen over homoseksualiteit, die stuk voor stuk steunden op de joods-christelijke cultuur en heersende medische theorieën waarin lesbiennes en homoseksuelen als zondaars, zieken en ontaarden werden bestempeld. Ze werden er bovendien van beschuldigd mee verantwoordelijk te zijn voor de nationale achteruitgang vanwege hun als 'niet-reproductief' beschouwde seksualiteit, zelfs al waren sommigen gehuwd en hadden ze kinderen. Even schadelijk waren de breeduit in de pers becommentarieerde schandalen, waardoor het hardnekkige beeld van de decadente homoseksueel, de verdorven aristocraat en de sadistische liefhebber van kleine jongens ingang vond ${ }^{1}$ In deze vruchtbare bodem zou het nazivertoog wortel schieten. Het werd later concret toen een steeds radicaler en uitdeinend bestraffingssysteem werd ingevoerd. De deportatie en dood van verschillende duizenden homoseksuelen vormden daarvan het misdadige hoogtepunt.

\section{NAZISME EN HOMOSEKSUALITEIT, EEN AMBIGU DISCOURS}

Uit de onderdrukking die homoseksuelen vanaf 1933 te beurt viel, bleek duidelijk dat het nazisme radicaal tegen homoseksualiteit gekant was. Toch ontwikkelde het naziregime daaromtrent nooit een samenhangend vertoog, waardoor de verwarring in stand werd gehouden over wat nu eigenlijk de bedoeling was. Zo tolereerde de NSDAP in haar midden lange tijd notoire homoseksulen als Enst Röhm, hoofd ( Ernst Röhm, hoofd van de SA maar ook lid van de BfM (Bund für Menschenrecht), een homoseksuele organisatie ten tijde van de Weimarrepubliek (Heinemann 2002). Bovendien had het regime vaak een voorkeur getoond voor een homo-erotische esthetiek. Dat was zowel te merken aan de artistieke productie (monumentale beeldhouwwerken van Arno Breker en Joseph Thorak) als aan de grote naziparades waar de agressieve viriliteit van soldaten in uniform werd benadrukt, maar ook aan de sfeer van mannelijke kameraadschap in de Hitlerjugend (Theweleit 2015). ${ }^{2}$ Vanaf 1932 werden dergelijke contradicties uitgebuit door de linkse pers en vervolgens ook door de communistische propaganda, die vanaf 1934, in navolging van Gorki, homoseksualiteit bestempelde als een 'fascistische perversie'. Het cliché van de nazihomoseksueel, war Klaus Mannin 1934 no he waar Ke seid door som

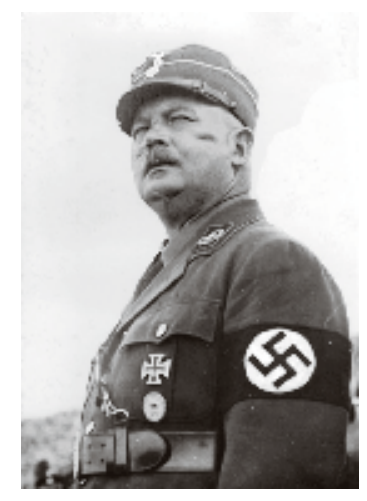

-Ernst Röhm

(1) In 1907-1908 werden de Disse aristocratie en militaire vriend van de Kaiser Daardo ontstond in Europa het beeld van (2) Denk maar aan Leni
Riefenstahls Triumph des Willens
(1934-1935) en haar enscenering van Arische lichamen tijdens de Olympische Spelen van Berliji in
1936 (Olympia, 1936-1938). 
Toch moeten we een onderscheid maken tussen enerzijds het gebruik van vriendschaps- en solidariteitsbanden tussen mannen voor politieke doeleinden, meer bepaald via de mythe van de door Hans Blüher theoretisch onderbouwde Männerbund (mannengroep) ${ }^{3}$, en anderzijds homoseksualiteit in strikte zin. Net omdat het naziregime en in het bijzonder zijn eliteorganisaties stoelden op het principe van mannelijke solidariteit moest koste wat het kost verwarring worden vermeden tussen soms tedere of zelfs vurige uitingen van viriele kameraadschap, en homoseksualiteit als een geseksualiseerde veruitwendiging van mannelijke lust. en homosekelijke lust. Homoseksuele relaties vertroebelden bovendien vaak de hiërarchische grenzen en deden zo afbreuk aan de discipline die voor een paramilitaire beweging onontbeerlijk is. Tot slot zou bij schandalen de eer zelf van de instelling worden aangetast. ${ }^{4}$ Naast het discours van de viriele vriendschap ontwikkelden bepaalde leidinggevende nazi's, in de eerste plaats Heinrich Himmler, al snel een radicale homofobe retoriek. Al in 1927 en 1928 had de NSDAP zich in de Reichstag heftig uitgelaten tegen een mogelijke afschaffing van paragraaf 175. Bij meetings in München hadden naziactivisten Magnus Hirschfeld hard aangepakt. Volgens de nazi's had een homoseksueel geen sociale waarde. Als hij zich, in een context van demografische angst en strijd voor de verovering van Lebensraum, niet wilde schikken naar de eisen van de Duitse otie (namelijk trouwen en kinderen krijgen), moest hij worden uitges de Duitse (In zijn toespraak sualiteit met een buitenlands inportproduct (het gevolg van rassenvermenging en meer bepaald Joodse invloed) en de homoseksueel met een potentiele verrader Voortbouwend op toen populaire medische theorieën maakte hij onderscheid tussen 'echte' homoseksuelen - zij bij wie homoseksualiteit zou zijn aangeboren en dus definitief was, maar die slechts een kleine minderheid vormden - en zij die waren 'verleid' en volgens hem dus konden worden 'genezen'. Vandaar dat hij tijdens de oorlog interesse opvatte voor 'medische' experimenten (psychiatrische of hormonale behandeling, castratie), want op die manier hoopte hij homoseksuelen naar het front te kunnen terugsturen zonder gevaar voor 'besmetting' (Himmler 1998).

Op dit vlak was Hitlers positie vooral pragmatisch Over ho (Hoksuliteit had Op dit vlat had hij geen specifiek vertoog ontwikk seksuelen binnen zijn eigen partij. Dat hij uiteindelijk tot bestraffing neigde, kom

\section{BESTRAFFINGSFASEN: EEN STAPSGEWIJZE IMPLEMENTERING}

Tijdens de eerste maanden na de machtsovername werd de Duitse homoseksuele subcultuur vernietigd, met name in Berlijn. Hermann Göring, de Pruisische minister van Binnenlandse Zaken, vaardigde drie verordeningen uit 'om openbare onzedigheid tegen te gaan'. Vanaf februari 1933 leidde dat tot een eerste repressieve golf tegen onder anderen prostituees en travestieten, homoseksuele bars, clubs en peeshotels, en ook tegen het uitlenen of verkopen van alle mogelijke 'onzedige' publicaties. Op 6 mei 1933 werd Magnus Hirschfelds Institut für Sexualwissenschaft

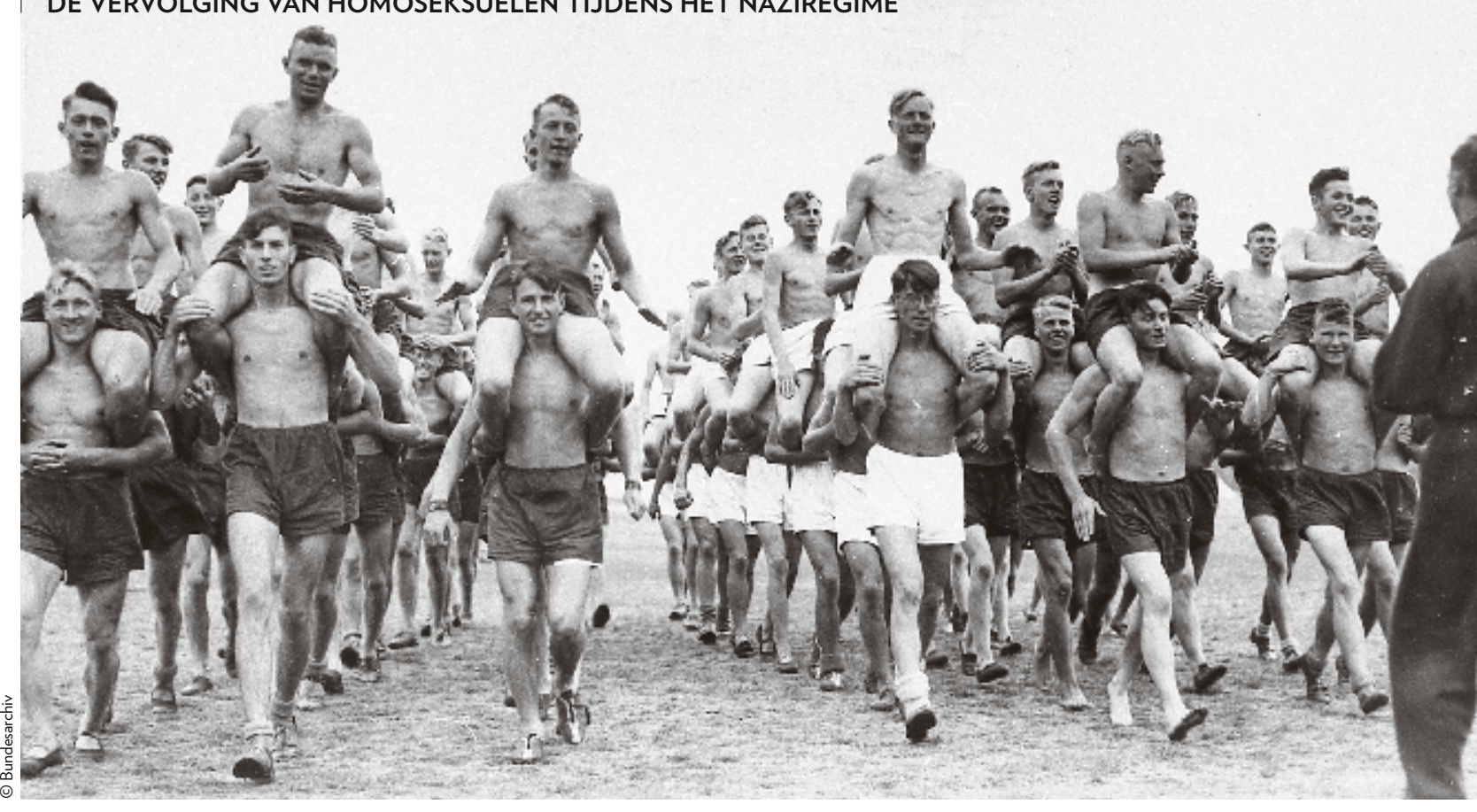

in Berlijn geplunderd. Het WhK werd in juni 1933 ontbonden. De meeste andere homoseksuele bewegingen verkozen zichzelf op te heffen Hun tijdschriften werden verboden en hun ontmoetingsplekken gesloten. Enkele bars stonden evenwel onder bescherming van de SA. Bepaalde steden werden later getroffen: in 1934 vonden razzia’s plaats in Keulen en pas in 1936 ook in Hamburg. In Kassel bleef een afgeslankte afdeling van de Bund für Menschenrecht in 1938 in het geheim samenkomen. Voor Duitse homoseksuelen brak een periode aan van geheimhouding en angst: sommigen kozen voor ballingschap, anderen gingen schijnhuwelijken aan, soms met een lesbische partner. De meesten leidden een dubbelleven, want op elk moment konden ze het slachtoffer worden van een politie-inval of verklikking (Micheler 2002). Mar bepald homoseksuele kunstenars die bescherming genoten vauwege het Maar bepaalde hom

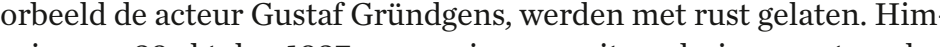
mlers verordening van 29 oktober 1937 voorzag immers uitzonderingsmaatregelen voor deze groep mensen.

In eerste instantie concentreerde de strijd tegen homoseksualiteit zich op bepaalde, in het oog springende categorieën. Op 10 februari 1934 stelde een verordening van het ministerie van Binnenlandse Zaken dat er regelmatig toezicht moest zijn op 'professionele misdadigers' en 'de gebruikelijke seksuele misdadigers', onder anderen pedofielen en homoseksuele prostitués. Als ze niet meewerkten, kon de criminele politie (Kripo) hen in 'preventieve hechtenis' nemen (Grau 1995). ${ }^{5}$ De gevangenen werden vervolgens overgebracht naar het detentiecentrum Columbia-Haus in Berlin-Tempelhof, wa ze on fobrokn fysiek en mental werden gefolterd. De volgende halte was het concentratiekamp Lichtenburg. Sommige gevangenen
waren zelfs niet eens voor een rechter verschenen.

\section{-Mannelijke
kameraadschap in de
Hitleriugend.}


De 'Nacht van de lange messen' (29-30 juni 1934) luidde een periode in van zwaardere onderdrukking. Het uitschakelen van de SA-aanvoerder, vooral ingegeven door partijpolitieke overwegingen, werd door Hitler voorgesteld als een kruistoch tegen de onzedelijkheid. Daarna werd de beschuldiging van homoseksualiteit vaak gebruikt om tegenstanders in diskrediet te brengen, zowel in jeugdbewegingen (Sternweiler 2000b) als in het leger (Koch 1986) en de katholieke kerk (Hockerts 1971). Een speciaal bureau binnen de Gestapo werd belast met homoseksuele zaken (Sonderdezernat Homosexualität). Eind 1934 moesten alle regionle bureaus van (Sonder de crininele stonden, in het bijzonder leden van naziorganisaties. Op 1 september 1935 werd een nieuwe, gewijzigde paragraaf 175 van kracht. Elke daad gemotiveerd door seksuee verlangen voor een andere man was voortaan strafbaar, zelfs simpele strelingen. Voor de ernstigste gevallen (prostitutie, geweldpleging en gezagsmisbruik) kon de straf oplopen tot tien jaar dwangarbeid. Vrouwelijke homoseksualiteit bleef buiten schot (Eschebach 2012).

Na een duidelijke pauze in 1936 vanwege de Olympische Spelen in Berlijn gebeurde het bestraffen van homoseksuelen stelselmatig, conform een geheime order die Himmler op 10 oktober 1936 uitvaardigde. Binnen het Reichskriminalpolizeiamt (RKPA) werd lo okn fung der Homosexualität und der Abtreibung (Rijkscentrale voor de Bestrijding van noseksuele gevallen moest registreren, op fiches zetten en classificeren (Grau 1995, 88-91). ${ }^{6}$ In
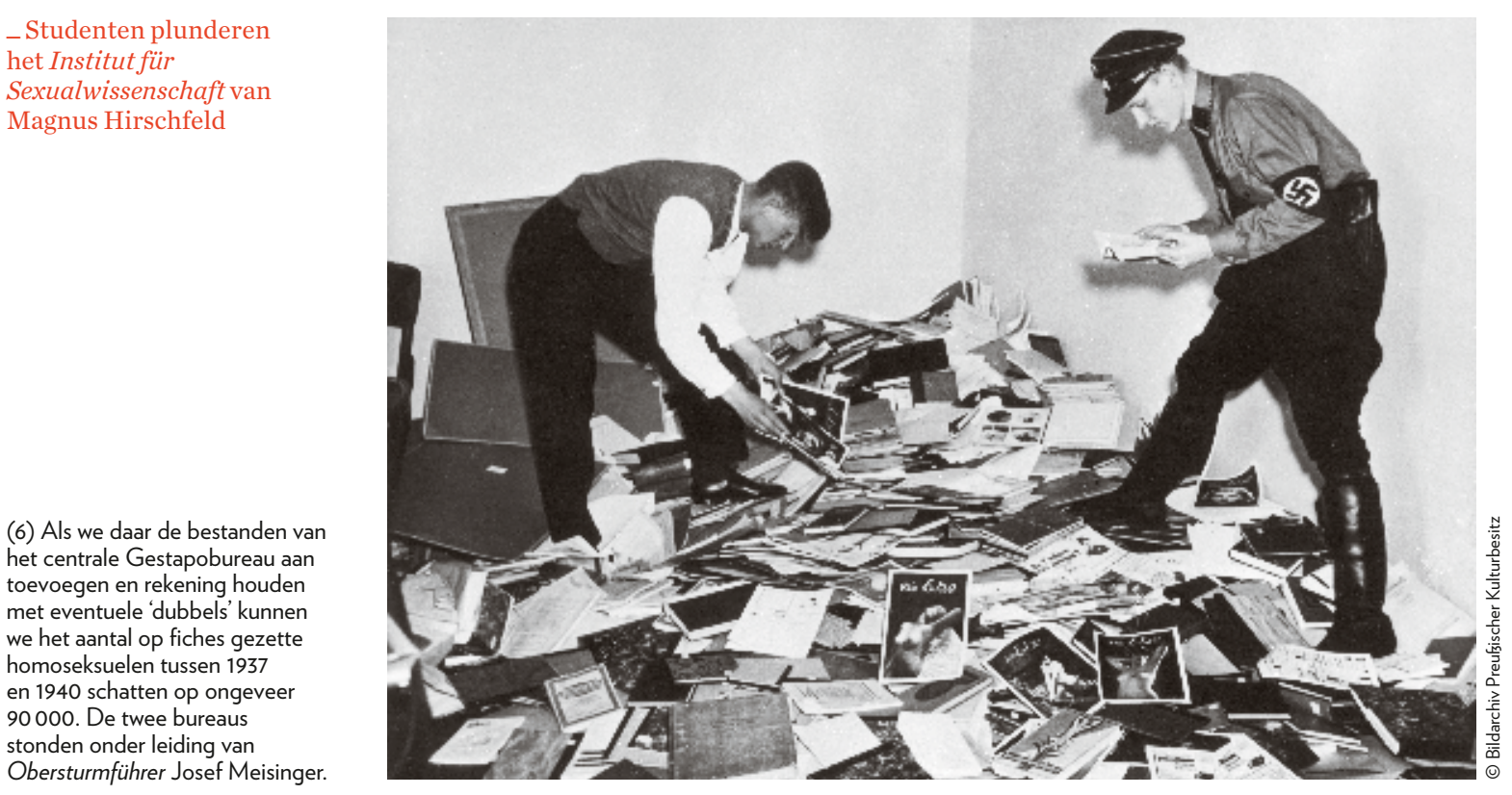

de steden werd een systematisch, fijnmazig controlenet opgezet: wegen, stations, parken, urinoirs, arbeidsbureaus en bars werden speciaal in de gaten gehouden en de bevolking werd tot verklikking angezet. Hotelportiers, bezorgers, taxichauffeurs, gezondheidspersoneel, kappers en bedienden van badinrichtingen werden vaak ingezet als tipgever. Die procedures waren niet vrij van uitwassen. In september 1937 ontstond namelijk schandaal toen leden van de politie in Frankfurt am Main ervan beschuldigd werden zich als agent-provocateurs te hebben gedragen om homoleksuelen in de val te lokken; ze zouden zich zelfs hebben laten afzigen om een schuldbewijs te verkrijgen (Grau 2000; Hoffschildt 1999; Limpricht 1991; Plötz 2002; Sparing 1977; Till 2000; Wahl 2004).

Het lot van de opgepakte homoseksuelen was uiteenlopend. Tussen 1934 en 1938 steeg het aantal berechte personen met meer dan factor tien en de uitgesproken straffen waren ook zwaarder. De straffen met gevangenschap werden langer, vooral die boven de drie jaar en de veroordelingen tot dwangarbeid. Toen de oorlog uitbrak, daalde het aantal veroordelingen, waarschijnlijk omdat de strijd tegen homoseksualiteit toen niet langer een prioriteit was en het land zijn energie op andere terreinen inzette. Bovendien kregen veel homoseksuelen een dekmantel door dienst te nemen in het leger. ${ }^{7}$

Hoewel de meeste homoseksuelen een gevangenisstraf kregen, werd een minderheid na het uitzitten van hun straf naar een concentratiekamp gestuurd voor 'heropvoeding' door arbeid. De anderen werden ingelijfd bij de Wehrmacht. Nog anderen, die als geestesziek golden, werden naar een psychiatrische inrichting gestuurd en soms 'geëuthanaseerd'. Wie was veroordeeld door een militaire rechtbank werd terechtgesteld of ingezet bij zelfmoordopdrachten. Bepaalde categorieën van homoseksuelen golden als bijzonder gevaarlijk: 'bedervers van de jeugd' (die betrekkingen hadden met minderjarigen), prostitués en recidivisten werden vaak naar een concentratiekamp gestuurd nog voor ze berecht waren, soms zelfs zonder ooit te worden berecht (Grau 1995, 38-39). Bepaalde gevangenen konden dan weer worden vrijgelaten, ofwel voor een bijzondere gelegenheid (bijvoorbeeld in 1939 nar anleidingvandeverjardagvandeFührer), ofwelomdathungedragas bedigend akkoord verklaarden met medische experimenten. Die experimenten konden de vorm aannemen van een medische 'behandeling' van psychoanalytische aard, maar al snel werden ook radicaler middelen voorgesteld zoals verplichte of 'vrijwillige" castratie (Grau 1995, 250). Die laatste werd evenwel maar systematisch overwogen tijdens de oorlog, toen ze een manier leek om 'genezen' homoseksuelen weer naar het front te sturen. ${ }^{10}$

De bestraffing van homoseksuelen had tot slot alleen betrekking op onderdanen van het Rijk: Duitsers en inwoners van de bezette gebieden, meer bepaald Oostenrijkers. Elzassers en Lotharingers. Aangezien homoseksuliteit als een vorm van ontarding gold, kon het feit dat ze zich voordeed in nit-Duitse gebieden en bij 'minderwaardige' 'minderwaardige' bevolkingsgroepen alleen maar als onbelangrijk en zelfs gunstig
worden beschouwd. Dit verklaart waarom homoseksuelen in de door Duitsland
(7) Terwil het aantal voor
homoseksualiteit (\$ 175) berechte personen tussen 1919 bedroeg, waren het er 872 in 1934, 2121 in 1935 en 5556 1936. Voor 1937 beschikken
we alleen nog over het aanta veroordeelden, namelijk 8271 personen; in 1938 waren het personen). Vanaf 1937 slaan de
ciffers zowel op veroordelingen voor homoseksualitieit als

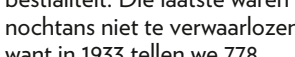
want in 1933 tellen we 778 personen die werden berech
voor homoseksualiteit en 213 voor bestialiteit. In 1940 waren er 3777 veroordelingen, in 1941
3739 in 19422678 V Vanf 1943 zijn de statistieken onvolledig.
De Wehrmacht had een speciaal bestand voor homoseksuelen, d (8) In Auschwitz en
Sachsenhausen werden homoseksuelen in het raam van hun 'heropvoeding' naar het

(9) Sommige homoseksuelen in de kampen stemden in met een
operatie in de hoop op vrijlating (10) In juli 1944 vonden in plaats onder leiding van de
Deense dokter Carl Peter Deense dokter Carl Peter homoseksuelen wilde 'genezezen' met een zelfbedachte hormonal 
bezette gebieden een heel ander lot kenden. In Nederland, dat in mei 1940 door Duitsland was bezet, werden homoseksuelen niet systematisch vervolgd, hoewel paragraaf 175 er samen met sectie 248 bis (verordening 80/41) werd ingevoerd (Hekma 2004). In Frankrijk was paragraaf 175 alleen van toepassing op de bij het Rijk gevoegde Elzas en in Moselle. Toch lijkt recent onderzoek erop te wijzen dat sommige Fransen wegens homoseksualiteit werden gedeporteerd uit bezet Frankrijk (in het bijzonder Parijs) en ook in het raam van de Service du Travail Obligatoire (B) (Bertrand 2011; hlagdenhauffen 2014).

Niet alle homoseksuelen werden dus over één kam geschoren en er was nooit sprake van het 'uitroeien' van alle homoseksuelen. Zoals Micheler, Müller en Pretzel het stellen: 'Het doel van het nazibewind was het uitroeien van homoseksualiteit niet van de homoseksuelen, zelfs al kwam het daar in veel gevallen praktisch op neer.' $(2002,8)$

\section{HET LOT VAN DE 'ROZE DRIEHOEKEN'}

Op 30 maart 1933 ging Dachau open, het eerste concentratiekamp dat vervolgens model stond voor Sachsenhausen, Buchenwald en Mauthausen. Onmiddellijk na de modelstond machtsovername werden er mannen opgesloten krachtens paragraaf 175: vanaf 1933 werd Egon Wüst, een van de stertravestieten van het cabaret Eldorado, naar Dachau gedeporteerd, terwijl WhK-activist Kurt Hiller naar Oranienburg werd gebracht. Sachsenhausen herbergde homoseksuelen vanaf 1936. Maar in de meeste kampen vormden homoseksuelen een zeer kleine minderheid, minder dan één procent van het totale aantal. Gedeporteerde homoseksuelen werden trouwens niet meteen geïdentificeerd met een roze driehoek - die werd pas in 1937 in Dachau ingevoerd (Knol $2002)^{11}$ - maar met het getal 175 en daarna met rode banden met zwarte stippen. In Lichtenburg waren ze te herkennen aan gekleurde banden op de dij en de letter A (voor Arschficker). In Sachsenhausen droegen homoseksuelen eersthetbruin en het (vert van de asocialen. De roze driehoek werd er ingevoerd in de zomer van 1938. Diet op eenvormige wijze wer tie en de burgerlijke en militaire rechtbanken, zo kon het lot van homoseksuelen binnen de concentratiekampen ook sterk variëren al naargelang de functie van he kamp en de datum van internering. Andreas Sternweiler onderscheidt drie perioden betreffende de geschiedenis van homoseksuelen in Sachsenhausen. De eerste (najaar 1936 - najaar 1939) komt overeen met de bouw van het kamp en de eerste transporten van gedeporteerden, die vooral naar Lichtenburg werden overgebracht. Ze ging gepaard met een toenemend aantal homoseksuelen, maar ook met sporadische vrijlatingen. Homoseksuelen werden verspreid over het kamp. Zoals alle gevangenen moesten ze vernedering en depersonalisatie ondergaan, en waren ze het mikpun me van sadistische b geken ook de interneringsomstandigheden. Tijdens deze periode (de zwaarste) was syste- matische uitroeiing de bedoeling. De homoseksuelen waren ondergebracht in een afgescheiden deel van het kamp en tussen april 1940 en april 1943 zouden 600 van hen vermoord zijn, met een piek tussen juli en augustus 1942. Tijdens de derde fase (zomer 1943 - januari 1945) steeg het aantal homoseksuelen opnieuw en trad er een relatieve verbetering op van hun situatie in het kamp, terwijl des prioriteit uitging naar het inzetten van gevangenen voor de oorlogsindustrie (Sternweiler 2000a).

Zoals de andere gevangenen moesten de dragers van de roze driehoek onmenselijke inter hebben geleden. Ze werden vaak ingedeeld bij de Strafkompanie en moesten de zwaarste taken uitvoeren.Eugen Kogon vermeldt dat in vergelijking met andere groepen meer homoseksuelen naar de steengroeven in Flössenburg, Sachsenhausen, Buchenwald en Mauthausen werden gestuurd. Heinz Heger (1981) heeft het over afmattende arbeid in de leemgroeven van Sachsenhausen en over sadistische spelletjes van de bewakers. In Buchenwald werden de 'roze driehoeken' vaker dan anderen naar de vernietigingscentra Nordhausen, Natzweiler en Gross-Rosen gestuurd. Door het gebrek aan arbeiders kwam er een korte adempauze: in de zomer van 1942 werden ze samen met de andere gevangenen aan het werk gezet in de oorlogsindustrie en in januari 1944 werden ze gedeporteerd naar kamp Dora, waar de V2 werd geproduceerd De arbeid - huisvestings-en hygïnischeomstandigheden warenverschrike(a) lijk en de meesten stierven. Ook is het waarschijnlijk dat de meeste homoseksuelen in Buchenwald gecastreerd wer sche experimenten net buiktyfus. In Dachau zouden ze bovendien de geliefkoosde proefpersonen zijn geweest voor medische experimenten met malaria, hoewel het kamp zich kon laten voorstaan op het hoogste overlevingscijfer van geïnterneerde homoseksuelen: bijna veertig procent.

De problemen die de 'roze driehoeken' ondervonden, werden nog verergerd door de afzonderingsmaatregelen die in 1934 op initiatief van Rudolf Höss werden ingevoerd in Dachau, en vanaf 1938 in Sachsenhausen en Auschwitz. Homoseksuelen werden overd g gescheiden van de andere gevangenen en's nachts in een surak sameng obracht om zo elk risico op 'besmetting' te vermijden. Ook onderling baraks was verboli contact was ver slapen, met de handen duidelijk zichtbaar op de deken, want jullie nichten zouden nog een manier vinden om jezelfte bevredigen' (Heger 1981,48). Maar soms kon de nachtelijke afzondering niet worden gehandhaafd, bijvoorbeeld in de kampen in Ems en Rodgau, en werd het 'aanlengingsprincipe' toegepast: onder het vijandige toezicht van andere gevangenen werden de homoseksuelen verspreid over verschillende blokken. De facto mochten homoseksuelen vanwege hun bijzondere statuut geen hulp van buitenaf krijgen. Uit angst zelf als homoseksueel te worden beschouwd durfden hun vrienden geen brieven te sturen en vaak wilde hun familie niets met hen te maken hebben (Grau 1995, 275-279). De andere groepen gevangenen vermeden henom hen ond ze hertrouwden, in de overtuiging dat de SS hS-be- wakers en kapo's seksualiteit gebruikten als middel om de hiërarchie in het kamp

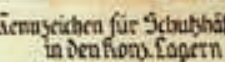


te bevestigen - bijvoorbeeld door jonge gevangenen (vaak Polen of Russen) uit te kiezen als knuffeljongens (Pielpel) - versterkte nog de verwarring: enerzijds had je praktijken die leken op machtsmisbruik en verkrachting in een context van seksuele frustratie, anderzijds was er de angst om als homoseksueel te worden geïdentificeerd. Nochtans bekleedden de 'roze driehoeken' geen sleutelfuncties in de rangorde van gevangenen en waren ze bijna nooit kapo. Ook de onderlinge solidariteit lijkt beperkt te zijn geweest. Bovendien hadden ze door hun geringe aantal in het kamp geen doorslaggeven invloed. In bepaalde per kamphiërarchie, net boven de Joden.

Het lot van lesbiennes is niet zo makkelijk te beoordelen. Lesbische geaardheid was zoals vermeld niet strafbaar en als lesbiennes werden aangehouden, gebeurde dat vaak onder een ander voorwendsel. Soms is er sprake van een roze driehoek met LL (Lesbische Liebe) erin, maar veel lesbiennes zouden zijn geregistreerd als politiek gevangene (rode driehoek), asociale (zwarte driehoek) of misdadiger (groene driehoek) (zie Schoppmann 1991).

We vinden alleen versnipperde sporen van het feit dat er lesbiennes waren in de kampen, waar ze vaak het slachtoffer zouden zijn geweest van seksuele vernederingen en verkrachtingen. Daarnaast ontstonden er, net als bij de mannen, homoseksuele vriendschappen in de kampen, maar die werden streng bestraft la licht kwanen. De stra kongan (van 25 tot 100), opsluiting in de bunker, het onderbrengen in het tuchtbataljon,

Was het nazibeleid rond homoseksualiteit dan uniek? Het was onmiskenbaa apart, wat mag blijken uit het gebruik van politieterreur, het dehumaniseren van slachtoffers, de bovenmaatse straffen, het streven naar absolute controle. Maar een dergelijke vervolging werd mogelijk gemaakt door het feit dat politie en gerecht vooraf al repressief te werk gingen, en dit vanaf 1871. Bovendien was Duitsland geen uitzondering, want de gebruikte methoden (toezicht houden op ontmoetingsplekken inzetten van agents-provocateurs enzovoort) waren van toepassing in heel wat andere landen. De medische uitwasen lijk' ijken 'netpsychiatrischemiddelenonder gebruk castratie onderzoek in Denenarken en Zwitserland. Het einde van de Tweede Wereldoorlog betekende niet dat de antihomoseksuele wetten werden afgeschaft. Homoseksuelen die onder het nazisme waren vervolgd, hielden zich bijgevolg gedeisd. Paragraaf 175 bleef tot 1969 van kracht in de Bondsrepubliek Duitsland (BRD) en tot 1968 in de Duitse Democratische Republiek (DDR). Aangaande seksuele meerderjarigheid bestond er tot 1989 discriminatie in de BRD en tot 1994 in de DDR, en daarna in het eengemaakte Duitsland (Hoffschildt 2002). ${ }^{12}$

Volgens een ronde schatting op basis van de officiële Rijksstatistieken en de bewaard gebleven nazistatistieken zouden ongeveer 100000 homoseksuelen zijn geregistreerd door de Reichzentrale zur Bekämpfung der Homosexualität und der Abtreibung. Meer dan 50000 van hen werden veroordeeld. Als we mogen afgaan op de cijfers van Rüdiger Lautmann (1977) die tot op vandaag de minst omstreden hypothese vormen, werden tussen de 5000 en de 15000 daarvan gedeporteerd naar de concentratiekampen. Daar kwamen de meesten in tragische omstandigheden om het leven. Aangezien de toenmalige homoseksuele populatie in Duitsland op 1,5 à 2 miljoen wordt geschat is het duidelijk dat de grote meerderheid de naziperiode wist te overleven. Maar stuk voor stuk waren ze een doelwit voor het regime en ze leefden aldoor in angst en schande.

Deze bijdrage is een ingekorte versie van het artikel 'La déportation des homosexuels durant la Seconde Guerre
mondiale', Revue déthique et de théologie morale 239, 2006, p. 77-104.

BIBLIOGRAFIE

- Michael Bertrand, La déportation pour motif d'homoseksualité en France,

Insa Eschebach (red.), Homophobie und Devianz. Weibliche und
männliche Homosexualität im Nationalsozialismus, Berliji: Metropo 2012.

- Günther Grau, Hidden Holocaust ? Londen: Cassell \& Co, 1995
[vertaling uit het Duits: Homosexualititat in der NS-Zeit: Dokumente [vertaling uit het Duits: Homosexualität in der NS-Zeit: Dokumente
einer Diskriminierung und Verfolgung, Frankfurt am Main: Fischer
Taschenbuch Verlag 1993].

- Heinz Heger, Les hommes au triangle rose: journal d'un déporté
homosexuel 1939-1945, Parijs: Persona, 1979/1981. - Elisabeth D. Heinemann, 'Sexuality and Nazism: the Doubly
Unspeakable Question', Journal of the History of Sexuality, 11(1-4), 2002, 21-66.

- Gert Hekma, Homoseksualitiei in Nederland van 1730 tot de modern
tijd, Amsterdam: Meulenhoff, 2004 .

. - Hans Günther Hockerts, Die Sittlichkeitsprozesse gegen Katholische
Ordensangehörige und Priester 1936-1937. Mayence: Mathias Ordensangehorigige und
Grunewald Verlag, 1971.

- Rainer Hoffschildt, Die Verfolgung der Homosexuellen in der NS-Zeit.
Zahlen und Schicksale aus Norddeutschland, Berlinn: Verlag Rosa Winke Zahle.

---., "140 000 Verurteilungen nach "\$ 175", Invertito 2, 2002, 140-149. - Burckardt Jellonnek, Homosexuelle unter dem Hakenkreuz, Paderborn:
Schöningh 1990 . Albert Knoll, 'Homosexuelle Hättlinge im KZ Dachau', Invertito 4, 2002, 68-91.

- Friedrich Koch, Sexuelle Denunziation, die Sexualität in der politischen Auseinandersetzung, Frankfurt am Main: Syndikat, 1986. - Rüdiger Lautmann, Seminar: Gesellschafft und Homosexualität, Frankfurt
am Main: Suhrkamp Taschenbuch, 1977 . - Cornelia Limpricht, Jürgen Müller \& Nina Oxenius (red.), 'Verführte'
Männer. Das Leben der Kölner Homosexuellen im Dritten Reich, Keulen:
Kölner Vollksblatt Verlag, 1991.
- Stefan Micheler et al, 'Homophobic Propaganda and the Denunciation
of Same-Sex-Desiring Men under National Socialism', Journal of the of Same-Sex-Desiring Men under Nation
History of Sexuality 11(1-4), 2002, 95-130.

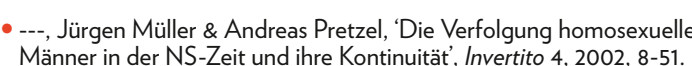
- Richard Plant, The Pink Triangle: The Nazi War against Homosexuals

Heinz-Dieter Schilling, Schwule und Faschismus, Berlijn: Elefanten Press,

- Régis Schlagdenhauffen, 'Désirs condamnés. Punir les '"
en Alsace annexée (1940-1945)?', Clio 39, 2014, 83-104

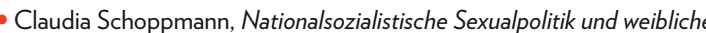
ät, Berlijn: Centaurus, 199

- s.n., 'Das sind Volksfeindel.' Die Verfolgung von Hon
und Ruhr 1933-1945, Keulen: El-De-Haus, 1998. Frank Sparing, ....wegen Vergehen nach 5175 verhaftet. Die Verfolgung
der Duisseldorfer Homosexuellen während des Nationalsozialismus, Düsseldorf: Grupello Verlag, 1997.

Andres Sternweiler, 'Chronologischer Versuch zur Situation der
Homosexuellen im KZ Sachsenhausen' in Joachim Müller \& An Steinweiler (red.), Homosexuelle Männer im $K Z$ Sachssenhausen, Berlijn:

--..' 'Homosexuelle aus der Jugendbewegung', in Joachim Müller \& Andreas Sternweiler, Homosexuelle Mämner im KZ Sachsenhausen,
Berlijn: Schwules Museum Berlin, Verlag Rosa Winkel, 20000, 109-144. - Florence Tamagne, Histoire de l'homosexualite
Londres, Paris. 1919-1939, Parijs: Seuil, 2000.

- Klaus Theweleit, Männerphantasien, Frankfurt am Main: Roter Stern
Verlag, 1979.

- Bastian Till, Homosexuelle im Dritten Reich. Geschichte einer Verfolgung. - Bastian Till, Homosexuelle im Dim

Niko Wahl, Verfolgung und Vermögung Homosexueller auf dem Gebiet
der Republik Osterreich während der NS-Zeit, München: Oldenbourg, 